\title{
The Venezuelan energy crisis: Renewable energies in the transition towards sustainability
}

\author{
Licia Pietrosemoli, Carlos Rodríguez-Monroy* \\ Department of Industrial Organization, Business Administration and Statistics, Universidad Politécnica de Madrid (UPM), c/José Gutiérrez Abascal, 2, 28006 Madrid, Spain
}

\section{A R T I C L E I N F O}

\section{Keywords:}

Sustainability

Competitiveness

Energy crisis

Energy transition

Power supply

Infrastructure

Venezuela

\begin{abstract}
A B S T R A C T
Modern society is aware of the importance of energy, as a fundamental resource for evolution, quality of life and sustainability. It thus dedicates important efforts to take advantage of existing energy sources. Countries have different and unique energy performances depending on the combination of resources, policies, and structures created to exploit them. Some are successful in their attempt to optimize their energy resources while others are not. This is the case of Venezuela, which faces a contradictory energy performance. Despite its substantial available renewable and non-renewable energy resources, it presents a severe energy crisis. This crisis manifests itself in frequent and extended energy blackouts and electricity services alterations, which affect all society. With the aim to propose some solutions, the authors make an attempt to identify the origin of the Venezuelan energy crisis, unexplainable in a country which two decades ago was an indisputable world energy leader. The authors evaluate the relationship among energy and sustainability, the renewable potential existing in Venezuela, as well as some new data and key insights regarding its energy framework. Special reference is made to infrastructure energy projects in Venezuela. The discussion leads to the identification of the structural problems that cause such a crisis and include some recommendations. The authors propose a thorough study of this case in order to consider it as an international reference and to avoid the repetition of similar cases in the future. Finally, an entirely new orientation of the Venezuelan energy framework and the strategies that include the revision of the current energy policies and the management of this sector are proposed. Such proposals are presented to help Venezuela in its transition to a new energy stage in which renewable energy, knowledge and sustainable criteria become the fundamental resources to address the country on its path to sustainability.
\end{abstract}

\section{Introduction}

Large sectors of society acknowledge the prominence of energy to support sustainability goals. This importance is especially recognized for renewable energy, with growing attention to the benefits that it can offer to provide "Sustainable Energy for All" goals, poverty reduction, growth and in general sustainable development. These benefits moti vate important efforts from society to create conditions for a better future.

Every country faces its challenges based on its own conditions. This is a complex context in which culture and knowledge, energy, re sources, transportation, infrastructure, technology, society, environment, policies, and investments become fundamental variables that need to be correctly handled in a very delicate balance that may permit to reach the established global sustainable goals. The combi nation of such variables makes every case unique with different results, some more successful than others.

Experts describe sustainability as the conscious production and use of the resources required for residential, industrial, transportation, commercial or recreational processes associated with mankind. This approach is based on a long term vision and on ethical, environmental and global fundamentals and considers individuals as beneficiaries of such efforts, to improve their quality of life through time $[1,2]$. Going forward with this perspective, Pagani [3] maintains the necessity to

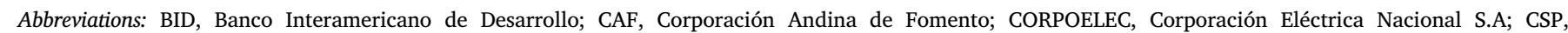

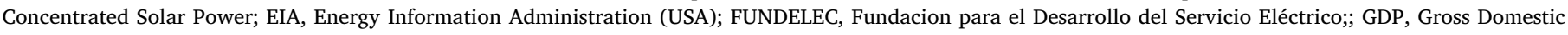

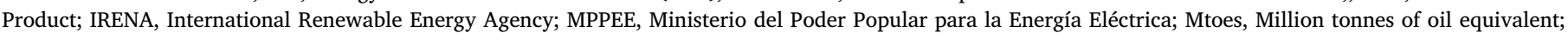

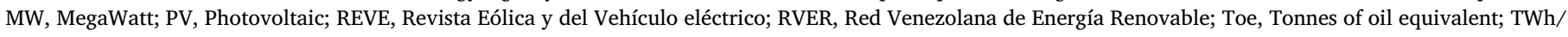
year, TeraWatt-hour/year; WP, Watt peak capacity

* Corresponding author.

E-mail address: crmonroy@etsii.upm.es (C. Rodríguez-Monroy). 
make the new resources and technologies competitive with direct costs compatible with the environment, trying at the same time to reduce indirect costs and thus avoid conflicts among the economic and the technical cultures. Sustainability is not a recent concern, since history shows evidence of the interest of different cultures about the con sequences of soil erosion, water, and energy shortages, worsening air quality or food mismanagements [4].

Besides that, another concept that is essential for every country is energy. This relevance arises from its use in job creation, transporta tion, and industry. In consequence, energy supports wealth growth and thus a country's development as well as social and environmental sus tainability [5]. This makes this resource a fundamental factor for sus tainable development and is considered the main challenge for devel oped and developing countries [2].

Apergis and Danuletiu [6] describe other positive benefits from energy since they find a bidirectional causality between energy con sumption and economic growth. Because of the positive causality re lationship, these authors consider that renewable energy supports economic growth and at the same time economic growth promotes the utilization of more renewable energy in a virtuous cycle that brings positive effects to the economy and society. Confirming such relevance Al Mulali et al. $[7,8]$, show a positive bidirectional long run relation ship between renewable energy consumption and GDP growth in a group of countries, with Venezuela among them.

All this makes relevant that in the sustainability equation, energy plays an essential role. In fact, several researchers conclude that energy, mainly renewable from solar, wind, geothermal, water, biomass and waste is fundamental to meet an important part of the world's energy demand and is needed to offer long term sustainable solutions, to create wealth, employment and new business opportunities $[9,10]$. The im portance of renewables in the current energy mix is evident. In fact, their market share is growing significantly. In $201517.5 \%$ of the world's final energy consumption came from renewable sources. An other relevant fact in that from such share, 9.6\% was produced by modern renewable energy systems from wind, solar, geothermal, bioenergy and hydropower sources. Along with that, the participation of renewable energies in power generation grew to $22.8 \%$ for the same year showing the important advances reached by many countries [11]. This improvement is a consequence of the extended concerns about the preservation of the environment and the use of renewables as sustain able energies.

The combination of conscious and proactive environmental con cerns along with public policies, new technologies, improvements in energy efficiency and electrification create the perfect conditions for the exploitation of the potential of these energies [12]. Experts warn about the need to accelerate the efforts to take advantage of such po tential and be able to control the increase of global temperature. This ongoing energy transformation demands additional and integral efforts in the policies to permit that electrification, transportation, and heating/cooling processes, sustainable construction, and energy effi ciency evolve in all sectors of the global economy for a better and sustainable world.

The efforts to follow a sustainability path and the motivations to transform the energy behavior have been addressed from different countries for years. Positive results have been reached in some aspects, such as energy access, the improvements in energy efficiency and electrification. In fact, in 2000 the group of people living without electricity reached 1.7 billion and due to the correct policies and in vestments, this was reduced to 1.1billion in 2017 showing important progress in energy poverty reduction $[11,13]$. But despite the progress made, severe inequalities persist in the world, with millions of people suffering the consequences of poverty, energy scarcity and social im balances $[5,14,15]$. This is evident when we consider that in spite of the advances achieved, experts calculate that in 2018 , close to $13 \%$ of the world's population, about 1 billion people, still lived without electricity $[11,12]$.
This is one of the reasons why the United Nations established the "Sustainable Energy for All" initiative that pursues the goal to offer universal access to sustainable energy as a key target to be reached by $2030[12,16]$ and this is why global society must progressively evaluate the results of current efforts to timely identify the opportunities to improve them.

In order to support all the sustainable initiatives from an integral perspective, it is also mandatory to evaluate the planning and the performance of infrastructure projects as the way through which energy goals can be achieved [17]. In fact, Pero et al. [18] highlight the strong relationship existing between construction, energy, and sustainability.

Besides that, sustainability efforts and energy efficiency also require the evaluation of the development and performance of the transporta tion systems and their infrastructure. In fact, Kreuzer and Wilmsmeier [19] state that transportation is one of the sectors with the highest energy consumption. In 2013 it consumed 13\% of the global energy demand. Venezuela was one of the countries with higher energy con sumption referred to transportation activities in the 19902010 period. The inadequate conditions of infrastructure, the dependence on fossil energy for transportation purposes, as well as the existing energy sub sidies, are considered amongst the reasons of such high transportation energy consumption in the Latin American and Caribbean region. The consequences of such regional performance, in general, are evident in increased energy costs, pollution, and the decrease in competitiveness. Therefore, to support sustainability efforts, all the Latin American and Caribbean countries, mainly Venezuela because of the particular set backs suffered in the last two decades, need to improve their infra structure conditions of roads, railroads, harbors, and airports. Ad ditionally, experts suggest as mandatory in this region the revision of the policies for energy subsidies and the improvement of energy effi ciency. With these changes, Latin American and Caribbean countries could create more sustainable energy consumption patterns, decrease fossil fuel consumption and reduce emissions to the environment and thus support the "Sustainable Energy for All" Initiative [19].

The close interconnection among all the variables involved evidence the relevance to include sustainability as a mandatory criterion in the new vision of energy, construction, transportation, and all the in dustries and services, in order to foster the creation of a healthy en vironment capable of supporting the balance between sustainability and competitiveness $[17,18]$. Despite its relevance, the ways to guar antee access to sustainable and affordable energy for all and fulfill sustainability standards are not easy. The complex variables involved, the limited resources, planning and construction problems, the avail ability of services, public policies, political and technological con straints, along with fast population growth become limitations to reach these fundamental goals [16]. The aim of this research is to introduce a very complex case: The Venezuelan energy crisis and the need to gen erate positive changes to mitigate it. This case draws the attention of researchers because of the contradictions existing in this country, rich in energy resources from water, wind, sun, oil, and gas, that until two decades ago was an indisputable world energy leader and today is confronted by severe energy shortages and sustainability limitations that create severe burdens to its competitiveness, development and especially to the quality of life.

In this research, the authors refer to the relationship existing be tween energy and sustainability and some of the progress made in global energy markets. Additionally, they highlight the role of renew able energies as a way to address sustainable solutions for the global economy as well as their potential to sustain the quality of life im provements. The research presents an overview of the approaches and efforts developed by different nations to meet their energy needs and the different results found, in particular in Latin America. The study includes the revision of the Venezuelan energy framework, with some key insights regarding the potential of the country in renewable and non renewable energy, the current conditions of ongoing electricity infrastructure projects and their impact on competitiveness and quality 
of life. The research makes evident some of the causes that may be behind the paradoxes of this country which is rich in resources but suffers a particular kind of energy poverty and where sustainability and competitiveness are clearly insufficient. The authors present some proposals to make a better use of the Venezuelan energy potential and highlight the role of renewable energy, knowledge and sustainable criteria to guide Venezuela on its transition into a new energy stage in which the new performance will lead to an improvement of the Venezuelan quality of life and the competitiveness of its economy.

\section{The Venezuelan energy framework}

Venezuela plays an important role in global energy markets. Along with the rest of Latin American countries, it has evidenced different stages on its energy evolution. The understanding of some relevant facts about this sector is needed to evaluate current conditions and chal lenges.

Aware of the importance of energy and its crucial role in social development, around the 1980s some Latin American countries sup ported different initiatives to modify their energy policies. The goal was to liberalize and decentralize their markets, to attract investments and to increase efficiency. Thus, the region became a pioneer in promoting reforms to create competitive energy markets. Starting with Chile in 1982 and followed by Peru, Bolivia, Colombia, and Venezuela there has been a transformation of the electric energy sector that included some degree of privatization of the power generation and distribution pro cesses $[5,20]$.

Chile, Argentina, and Brazil achieved significant benefits with these energy reforms and experienced improvements in labor productivity, in the quality of services and in the access to electricity for the population [21]. However, in some other Latin American countries, the changes led to problems, conflicts, and political rejection. Thus, the initial market reforms and decentralization processes were followed by others that implied returning to the State control of the energy system [5]. Vene zuela is one of such cases of reforms that led to important achievements in energy, followed by severe drawbacks, as described later.

Considering such inconsistencies, in particular with the Venezuelan performance that will be explained in depth, there is a need to establish a priority to continue with the efforts to invest for the development of alternative clean energies and energy efficiency as a fundamental ele ment for sustainability [22,23]. This evolution should reinforce the current advances in a steady transition from traditional fossil to re newable energies in the mid term.

Actually, energy markets provide evidence that renewable energies are the fastest growing form of energy in power generation, with wind, solar, bioenergy, and hydropower, among the energies that show in creasing participation in the energy mix $[11,24,25]$. This tendency is maintained by the important decrease in the cost of renewables with the support of investments, new technologies, and adequate policies. In addition, the positive attitude shown by several countries towards the efficient use of energy along with its low environmental impact proves their growing participation in the energy mix $[11,24]$.

In some of their scenarios for the period 20172050 the EIA [25] foresees that natural gas, along with renewables such as wind and photovoltaic (PV), will show a growing tendency in renewable gen eration and may displace hydropower in importance.

The Spanish experience with solar energy is one of the examples of energy success that can be used as a reference for other countries. In recent years, Spain dedicated policies and investments to take ad vantage of the best opportunities from its solar potential and thus be came a renewable energy leader [26].

Costa Rica and Nicaragua stand out as valuable examples in Latin America in their evolution towards an energy sector driven by renew ables. In fact, based on the adequate use of their renewable energy potential, mainly from geothermal, hydroelectric, solar and wind re sources and with the support of suitable public policies and investment, such countries are close to their goals. Costa Rica plans to cover $100 \%$ of its energy needs in 2021 with renewable energies while Nicaragua expects to supply $90 \%$ of its energy needs in 2020 with renewables. The support of suitable public policies and investment has been essential for the advances reached by both countries [27].

Latin America has another remarkable example in renewable energy evolution: Uruguay, which developed integrated partnerships among public and private organizations to design a suitable regulatory fra mework. In 10 years Uruguay reached the goal of supplying $95 \%$ of its electric power needs from renewable sources. Moreover, and showing very important progress in sustainable criteria, this goal was reached without subsidies or increasing the costs for society [27]. In 2018 this country became the first in Latin America to be close to $100 \%$ in meeting its power needs with the use of renewable energies [28]. These examples support the thesis of a world driven mainly by this kind of energies as sustained by several experts.

The international demand for energy has been growing steadily in the last years and is expected to increase in the future, driven by de mographic and economic growth, mainly related to emerging econo mies [29]. In accordance, in some of their energy scenarios, the EIA [25] predicts that the total energy production will grow more than $20 \%$ from 2016 to 2040 based on the increase of renewables, natural gas and crude oil production. Other experts expect that the renewable energy market share may reach $5575 \%$ of gross final energy consumption around 2050 [30].

The global community attests huge differences in energy perfor mance. While some countries have made important investments and show advancements in the development of renewable energy, others show low levels of electrification and investment in energy infra structure. In consequence, they suffer from energy scarcity that affects their quality of life. This contradiction makes evident the existence of limitations that must be addressed to take advantage of the existing energy resources and knowledge.

Latin America is a region that historically has shown an important consumption of renewable energy so it can make important contribu tions to global energy needs. In fact, more than $26 \%$ of the total primary energy used in this region comes from renewables, mainly from hy droelectric sources. Experts indicate that besides the hydroelectric richness, the region has significant wind and sun resources in wide geographical areas, so renewable energy potential is considered very important for the Latin American energy markets [24,31].

Despite its huge water, sun, wind, and fossil fuel resources available, Latin America has shown a low efficiency in the use of their energy potential. For this reason, it is still unable to generate all the energy needed to meet its population demands. Even if there are some ad vances in this field, the region confronts energy supply shortages and inefficiencies affecting millions of people $[5,32]$. This low energy effi ciency arises because in general the public policies and political deci sions have not been able to correct the existing structural limitations. In such a way, the investment efforts made have not been able to fully develop such renewable and non renewable energy potential and thus fulfill energy gaps [31].

To improve the performance of the electric power sector in Latin America in general, it is essential to consider the availability of the adequate energy policies [33], the support of investments and sus tainable construction criteria [17] and the acknowledgment of the lessons learned $[21,34]$ as described in the following sections.

Latin America evidences severe energy imbalances. In fact, the de cisions and reforms undertaken in some countries have led to positive trends in the energy sector that allowed the creation of a diversified energy mix with improved consumption patterns and thus reduced social vulnerability for important segments of their societies [22].

However, this is not the case in Venezuela. While some neighboring countries reached better energy performances, Venezuela still faces important shortages and evident inefficiencies. To understand the Venezuelan case and its opportunities for improvement it is necessary 
to make a reference to the development of its energy sector through the revision of some of its main variables as described in the following sections.

\subsection{Evolution of the Venezuelan energy framework}

The Venezuelan energy potential is known from pre Hispanic times. In fact, native peoples used crude oil and asphalt that naturally flowed from the soil, which they called "Mene", to waterproof canoes, for il lumination, and for medical purposes. Following such ancient dis coveries, the Venezuelan energy tradition started at the end of the 19th century with the beginning of commercial oil exploitation $[35,36]$. In 1878, a group of Venezuelan entrepreneurs founded the first oil com pany in Venezuela. This is considered the true beginning of the Vene zuelan oil era [35]. A few years later, the country's first electric com pany was created in the city of Maracaibo in 1888. This decade is known as the one that gave birth to the electric services in Venezuela [37].

In the following years, the investments and research confirmed the huge oil and gas potential and progressively turned Venezuela into an energy leader. In the beginning, the electric service in Venezuela was developed by uncoordinated approaches and technologies, with few regulations. Since 1900, the period considered of transition from the agrarian to the agrarian oil economy, the difficulties of interconnection, regulations, and controversies that arose among the different partici pants in the electricity market led to different energy practices and conflicts. In these years of changes, around 1950, Venezuela created the commission to study the Caroní river electric power development (Comisión de Estudios para la Electrificación del Caroní). This institu tion was created to develop the hydropower potential of the Caroni River, to reduce the dependence from fossil fuels, to switch to hydro power and to promote the industrial development of the southern Guayana region [38,39]. Important renewable energy infrastructures were built in such years. In two stages between 1963 and 1986, the Guri Dam (formerly Raúl Leoni and now Simón Bolivar Hydroelectric power station) was built. When completed, Guri became the second largest hydroelectric power generation plant in the world after Itaipú in Brazil, offering more than $10,000 \mathrm{MW}$ of electric power [37,38]. The Guri project was built following strict quality and sustainability standards along with severe financial and transparency controls imposed by the World Bank, which financed the project. Complementary to such con trols, in order to plan and build the dam, the construction experts es tablished indicators and knowledge management processes that to gether enabled the project to be finished within the expected time and budget. Therefore, Guri is considered an international reference in re newable infrastructure construction and one of the most emblematic hydroelectric plants ever developed [38].

The construction of Guri Dam enabled the supply of $70 \%$ of Venezuelan electric power needs and the reduction of more than 300,000 oil barrels per day formerly used as fuel to produce electricity. Consequently, the Guri Dam became a landmark in Venezuelan sus tainable energy history. In such years, the Venezuelan electricity sector reached an outstanding level of development with electrification cov ering more than $90 \%$ of the country. The transmission networks cov ered most of the populated regions and the different frequencies present at the time were finally unified [37].

Despite those advancements, the Venezuelan regulatory framework remained unchanged. The inexistence of a specific law for the elec tricity sector and the weak regulatory framework soon became serious limitations for the efficient development of the industry that evidenced a severe lack of planning and coordination among the different parti cipating organizations.

In the following years, the Venezuelan State adopted different in itiatives to take control of the electricity sector, leading to the con stitution of a State monopoly that soon regulated all the electricity in dustry including the prices and services rendered, and offered subsidies to some sectors [37].

The open market policies and advancements found in the Venezuelan electricity markets in the late 1990s reverted a few years later. At the end of the 20th century and under new political and management orientations, the country faced important changes in the electricity sector. Such changes caused mismanagement, more delays with investments in new plant construction and refurbishment, in en ergy distribution and in facilities' maintenance, with negative con sequences for the overall performance of the industry. In 2007 the State owned company Corpoelec took total control of the electric power sector [34], and the conditions of the Venezuelan electric system and services changed significantly once again [40].

\subsection{The current energy situation in Venezuela}

Currently, the Venezuelan situation in energy markets is complex. Oil and gas reserves make Venezuela one of the countries with the greatest hydrocarbon reserves in the world. In 2016, Venezuela had the largest total proved oil reserves in the world with a $17.6 \%$ share of the total. The country was also ranked seventh in natural gas with total reserves that account for $3.1 \%$ of total proved reserves in the world [24].

In addition to fossil energy resources, Venezuela is one of the main world producers of hydropower, with exceptional geographical and hydrological conditions for the development of new projects. In 2015 the country occupied the 9th position as a world producer of hydro electric power with a share of $1.9 \%$ of total hydroelectricity con sumption [41].

However, these potential results are underutilized. In fact, the IRENA [42] reports that in Venezuela the share of renewable energy decreased in the total primary energy supply between 2000 and 2012 due to the decrease of hydropower supply, while fossil fuel energy in creased. British Petroleum [24] also identified this behavior as Vene zuela evidenced the largest decline of all hydropower producers, with a diminution of $20 \%$ as it shifted from production of 17.3 Mtoe in 2015 13.9 Mtoe in 2016. In his research on Venezuelan energy per formance, Bautista [34] found that the country is exploiting only $66 \%$ of its important hydropower capability.

Far beyond this hydrological underused potential, Venezuela also presents vast renewable energy resources coming from the wind and the sun. The official references for solar and wind resources are scarce and do not show the real country potential. In compensation for this lim itation, different experts from universities and research centers work in the development of databases that may permit the true evaluation and use of such valuable resources. Among them, Salas [43] together with other experts that participate in the Red Venezolana de Energías Re novables (RVER) [44] (Venezuelan Renewable Energy Network) in dicate that the main potential in renewable energies development in Venezuela is related to thermo solar (Concentrated Solar Power, CSP), photovoltaic, hydropower and wind. Hernández [45] indicates that the Venezuelan solar potential for 2016 reached 228 Mtoe while Bautista [34] calculated it in 1465 TWh/year. Fig. 1, supplied by international sources of the World Bank ESMAP databases, shows evidence of the solar photovoltaic potential existing in Venezuela.

Together with solar energy, wind resources are also abundant in Venezuela. Hernández [45] estimates the wind potential to be 70 Mtoe. From his side, Bautista [34] considers that Venezuela could produce $1038 \mathrm{TWh} /$ year. The Venezuelan wind potential has been studied also by González Longatt et al. [46]. In this research, the authors identified the lack of information related to the Venezuelan wind resources as a high risk for the development of renewable projects and their com mercial exploitation. To offer solutions to such weakness they have built a wind power database to determine the Venezuelan potential. To create it the authors performed wind observations in 32 diverse weather stations in western, central and eastern regions of Venezuela, from 2005 to 2007. The authors cataloged the winds found from 


\section{PHOTOVOLTAIC POWER POTENTIAL}

\section{VENEZUELA}

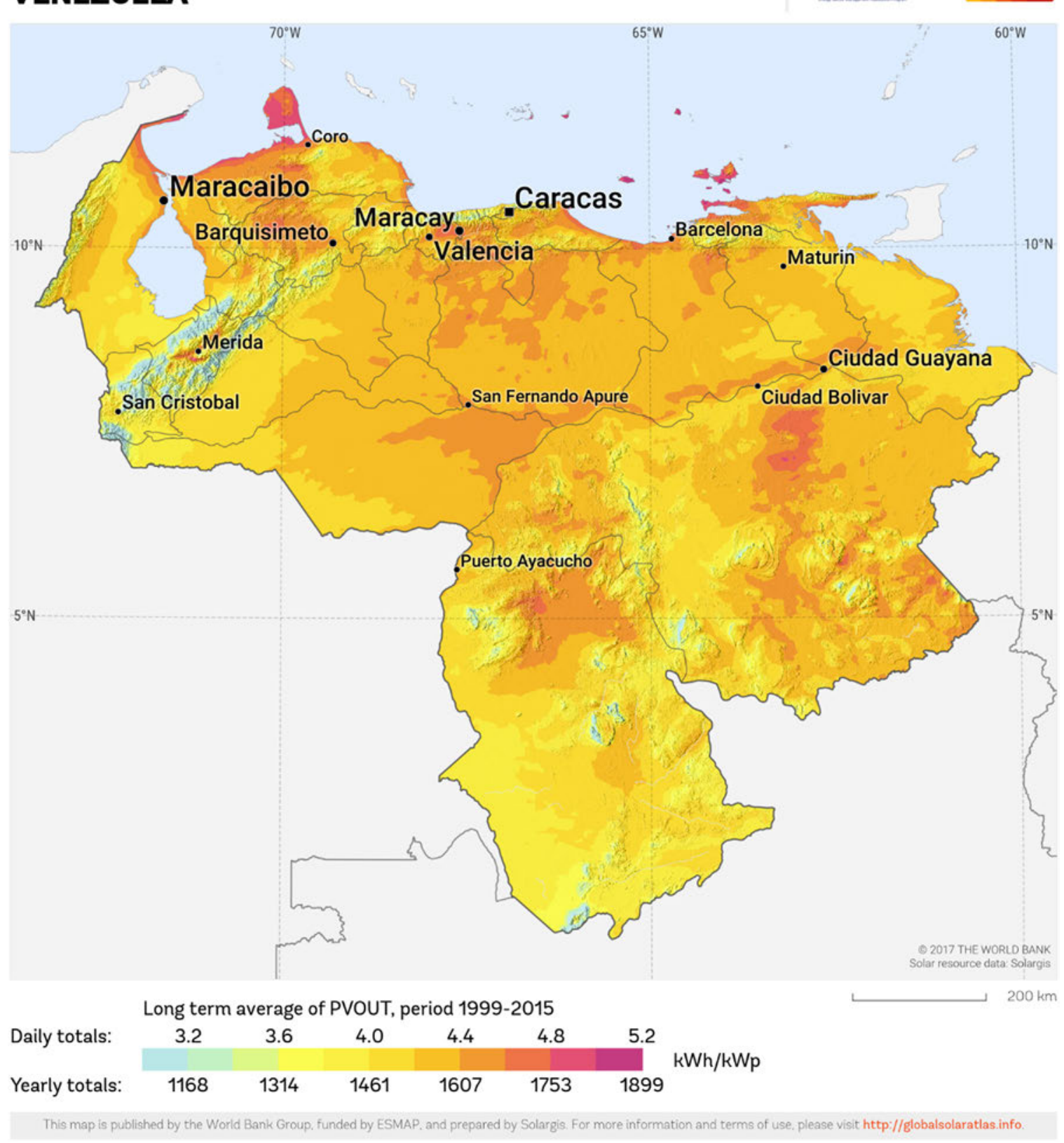

Fig. 1. Venezuelan photovoltaic power potential.

Source: https://globalsolaratlas.info/downloads/venezuela?c $=8.276727,-66.533203,5$.

moderate to excellent and determined that the best wind energy was found in the northern coastal areas of the country. They suggest such areas as suitable to develop wind energy projects.

In another research Gonzalez Longatt [47] found that the wind density together with wind speed in the Los Taques region of western Venezuela was estimated at $50 \mathrm{~m}$. The characteristics of the wind measured in this location along with its conditions during the year confirm that the Venezuelan wind resources can be qualified as high class and suitable as a commercial source to produce electric power.

Despite that these massive resources are available during most of the year, the wind and solar installed capacity in Venezuela is negligible [45]. As a consequence, most of these renewable energy resources re main underutilized. Regarding this underutilization, Bautista calculated that the Venezuela solar rate of use for 2012 only reached $0.000000127 \%$ of the national capacity. In reference to wind, this au thor considers the use of this potential as inexistent for the same year [34]. Such paradox is part of the Venezuelan energy crisis that causes severe consequences to Venezuelan society.

In addition to the underutilization of renewable resources, at the beginning of the 21 st century, Venezuela faced worse scenarios. In fact, the society started to confront with growing severity the weakening of the Venezuelan electrical services and as a consequence the energy deficits that today affect the quality of life of the population and the production activities [48 50].

Both the Venezuelan government and common citizens acknowl edge the existence of problems with the electricity supply. In fact, the 
Table 1

Electricity supply in Venezuela (MW).

Source: Authors' adaptation from [49,50].

\begin{tabular}{llll}
\hline & $\begin{array}{l}\text { Installed capacity } \\
\text { MW }\end{array}$ & $\begin{array}{l}\text { Available capacity } \\
\text { MW }\end{array}$ & $\begin{array}{l}\text { Unavailable capacity } \\
\text { MW }\end{array}$ \\
\hline Thermal & 17,600 & 6,500 & 11,100 \\
Hydropower & 16,500 & 10,000 & 6500 \\
Total MW & 34,100 & 16,500 & 17,600 \\
\hline
\end{tabular}

Venezuelan plan for the development of the national electrical system for 20132019 [51] highlights the operational unavailability of several facilities currently in operation and others to be installed and points out the necessity to install additional generation capacity to restore the energy balance.

\subsection{Past data and key insights}

The contradictions existing in Venezuela about its energy sector are made evident by some fundamental data collected in the following ta bles, that presents an overview of the Venezuelan electricity framework with an emphasis on the generation infrastructure. The major chal lenges related to such data are described in Section 2.4, Review of major challenges.

Table 1 shows the power unbalance in the Venezuelan installed capacity in 2015 comparing available and unavailable capacity.

Considering that in 2016 the Venezuelan total electricity demand was around $18,300 \mathrm{MW}$ there is a significant deficit of $1800 \mathrm{MW}$ $[49,50]$.

Tables 2, 3 present some details of the current advances of the main hydro and thermoelectric on going projects in Venezuela as well as the investments made for their development. Considering the scarce official information about such projects, and the need to complement it, in such tables the authors compare the official indicators presented by the State energy company, Corpoelec [52] with data collected by Salas [53] from other different researchers.

The data collected makes evident a severe delay in project com pletion together with the important amount of funds that, according to Corpoelec, were available to be allocated by the government for their implementation.

Tables 4, 5 describe some basic facts about the Venezuelan wind power and photovoltaic facilities existing or planned for the country.

As a consequence of the weak culture in the generation of indicators already mentioned, in Venezuela, there are few official statistics about renewable energy. The Web page for the Ministry responsible for electricity, Ministerio del Poder Popular para la Energía Eléctrica (MPPEE) [56], and the State energy corporation, Corpoelec [52], briefly mention some renewable energy initiatives. In such Webpages, there is no formal data for the advancements reached with renewable energy development so researchers and developers must work with other knowledge sources. Created in 2017, Red Venezolana de Energía Renovable, (RVER) [44] presents some data related to renewable energy developments in Venezuela and other countries. The RVER current report indicates that none of the wind parks projected in Ve nezuela is operational yet. Páez [57] presents similar results pointing out that the Paraguaná and La Guajira wind facilities are not yet in the production stage and that their infrastructures are almost abandoned. This author indicates that the Venezuelan renewable advances are limited to the existence of a few small hydroelectric power plants as well as individual PV and hybrid Wind PV Diesel units that supply limited amounts of unquantified energy.

The information available about the participation of renewable energies in the Venezuelan gross electricity generation is shown in Table 6.

Confirming such findings, Salas [59] presents some data about the participation of new renewable energy in Latin American countries. The study evaluated the energy provided by micro or mini hydro, wind, PV, biomass or hybrid energy in some Latin American countries in 2012 and found that unlike the other nations evaluated, there were no re ports of this kind of energies in the Venezuelan energy mix for 2012.

\subsection{Review of major challenges}

The data presented show the existence of major challenges in the Venezuelan energy field.

In fact, the data collected shows the unconceivable gap existing among electric installed capacity and electric availability, the severe delays with energy infrastructure construction or refurbishment pro jects and the scarce advancements with renewable energy development.

Although such adverse conditions damage the whole Venezuelan socio political and productive structure, in this research the focus is placed on Energy, as one of the sectors which cause the most severe distortions and limitations to the rest of the country.

As a consequence, the country faces today an energy crisis with no precedent in the world.

The current Venezuelan energy crisis is tightly linked to the struc tural problems caused by a political model which does not favor eco nomic independence, the diversification of the economy, competitive ness and sustainability. As a consequence, such Venezuelan structural problems create burdens and limitations that impede the performance improvement of other sectors of the nation.

Venezuela is not included among the countries described by inter national researchers as suffering energy poverty. Authors consider that this is because of the ample electrification and distribution grid that resulted from the efforts of entrepreneurs and governments that in the past worked for the energy development and created a strong and modern energy industry. But nowadays the reality is totally different and the energy scarcity suffered by the Venezuelan population explains the severity of the current energy crisis.

In Venezuela, industries, homes, schools, and hospitals depend on unpredictable electrical supplies. Therefore, society suffers from pro gramed electricity rationing as well as frequent, unexpected and long blackouts. This energy unbalance, negatively conditions lifestyle and production capacity, with severe consequences in the country's

Table 2

Venezuelan main electric generation projects evolution - hydropower.

Source: Authors' elaboration from: [52,53].

\begin{tabular}{|c|c|c|c|c|c|c|c|}
\hline Plant/project type & State & Capacity MW & $\begin{array}{l}\text { Project start } \\
\text { date }\end{array}$ & $\begin{array}{l}\text { Scheduled start- } \\
\text { up }\end{array}$ & $\begin{array}{l}\text { \% of completion Aug } 2018 . \\
\text { (Corpoelec) }\end{array}$ & $\begin{array}{l}\% \text { of completion Aug } 2018 . \\
\text { (Experts) }\end{array}$ & $\begin{array}{l}\text { Planned } \\
\text { investments }\end{array}$ \\
\hline Simón Bolívar (GURI)/R & Bolívar & $700 \mathrm{MW}$ & 2001 & 2014 & 35 & 35 & Bs. $2.106 \mathrm{MM}$ \\
\hline Manuel Piar (TOCOMA)/C & Bolívar & $2160 \mathrm{MW}$ & 2002 & $2012 / 2014$ & 66 & 66 & $\$ 5.996 \mathrm{MM}$ \\
\hline Fabricio Ojeda (La Vueltosa)/C & Mérida & $514 \mathrm{MW}$ & 2004 & 2010 & 72 & 72 & $\$ 361 \mathrm{MM}$ \\
\hline $\begin{array}{l}\text { Antonio J. de Sucre (Macagua } \\
\text { I)/R }\end{array}$ & Bolívar & $120 \mathrm{MW}$ & 2006 & 2014 & 44 & 44 & $\$ 325 \mathrm{MM}$ \\
\hline Masparro/C & Barinas & $25 \mathrm{MW}$ & 2005 & 2009 & 100 & 100 & $\$ 40 \mathrm{MM}$ \\
\hline
\end{tabular}

Project type: R: Refurbishment. C: Construction. 
Table 3

Venezuelan main electric generation projects evolution - thermoelectricity.

Source: Authors' elaboration from: [52,53].

\begin{tabular}{|c|c|c|c|c|c|c|c|}
\hline Plant/Project type & State & Capacity MW & $\begin{array}{l}\text { Project starting } \\
\text { date }\end{array}$ & $\begin{array}{l}\text { Scheduled start- } \\
\text { up }\end{array}$ & $\begin{array}{l}\% \text { of completion Aug } \\
\text { 2018. (Corpoelec) }\end{array}$ & $\begin{array}{l}\% \text { of completion Aug } \\
\text { 2018. (Experts) }\end{array}$ & $\begin{array}{l}\text { Planned } \\
\text { Investments }\end{array}$ \\
\hline Planta Centro/R & Carabobo & $400 \mathrm{MW}$ & 2002 & 2009 & 62 & 62 & Bs. $978 \mathrm{MM}$ \\
\hline Antonio José de Sucre/C & Sucre & $1000 \mathrm{MW}$ & 2004 & 2012 & 15 & 15 & \$ $1472 \mathrm{MM}$ \\
\hline Alberto Lovera/C & Anzoát. & $300 \mathrm{MW}$ & 2005 & 2010 & 48 & 48 & \$ $174 \mathrm{MM}$ \\
\hline Termozulia II/R & Zulia & $470 \mathrm{MW}$ & 2007 & 2010 & 70 & 70 & $\$ 551 \mathrm{MM}$ \\
\hline Termocentro/C & Miranda & $1610 \mathrm{MW}$ & 2007 & 2011 & 8 & 8 & Bs. $2187 \mathrm{MM}$ \\
\hline $\begin{array}{l}\text { Juan Manuel Valdez (Cigma)/ } \\
\text { C }\end{array}$ & Sucre & $900 \mathrm{MW}$ & 2007 & 2014 & 8 & 8 & $\$ 2250 \mathrm{MM}$ \\
\hline Ezequiel Zamora/C & Guárico & $150 \mathrm{MW}$ & 2005 & 2009 & 44 & 28 & $\$ 113 \mathrm{MM}$ \\
\hline Josefa Camejo/C & Falcón & $450 \mathrm{MW}$ & 2009 & 2009 & 92 & 92 & $\$ 2203 \mathrm{MM}$ \\
\hline San Diego de Cabrutica/R & Anzoát. & $300 \mathrm{MW}$ & 2008 & 2009 & 18 & 18 & $\$ 187 \mathrm{MM}$ \\
\hline $\begin{array}{l}\text { Juan Bautista Arismendi } \\
\text { (Termoisla)/C }\end{array}$ & $\begin{array}{l}\text { Nueva } \\
\text { Esparta }\end{array}$ & $316 \mathrm{MW}$ & 2009 & 2010 & N/A & N/A & N/A \\
\hline
\end{tabular}

Project type: R: Refurbishment. C: Construction.

competitiveness $[40,60]$. The Venezuelan energy imbalance keeps growing with increasingly frequent power failures and higher risks of a large national blackout that could occur at any moment [61].

In this regard, the Venezuelan situation is extremely serious. The lack of food and medicines, the highest hyperinflation in the world, the migrations of citizens to neighboring countries, the closure of in dustries, schools and hospitals, the extended blackouts and one of the highest crime levels in the world evidence the severity of the Venezuelan case.

This reality makes imperative the incorporation of structural changes in the energy sector after a planned and coordinated strategy. The changes must start with the acknowledgment of this unprecedented and unique problem that requires long term, multidisciplinary and in tegrated solutions.

As mentioned, the origin of the Venezuelan energy crisis comes from a combination of different reasons. Vidoza and Gallo [62] point out the damages caused by a weak regulatory framework because of the con tinued modifications of the legislation. Due to such changes, Venezuela suffers from a weakened policy framework that adds additional dis tortions to an already complex energy system. The problems confronted by the Venezuelan energy industry arise from the low hydrocarbon and electricity prices, extended subsidies and infrastructure project delays. Additional distortions arise because of the weak controls in production and distribution, political and non technical management of the energy industry, operational shutdowns and incidents, inefficiencies and technical losses, smuggling and black market practices for petroleum products. This already severe outlook is worsened by insufficient sup port for wind, solar and other renewable projects.

Contrary to some arguments used by public employees and gov ernment officials to justify this situation, different researchers point out that the Venezuelan electricity crisis is not a consequence of a lack of investments, sabotages or seasonal problems. In fact, during decades the Venezuelan government invested large amounts of resources to develop the electricity sector. Even if in the last ten years the intensity
Table 5

Venezuelan main electric generation projects evolution - photovoltaic systems. Source: [55].

\begin{tabular}{llll}
\hline & State & Units & Installed capacity MW \\
\hline $1.200 \mathrm{wp}$ & N/A & N/A & $0.97 \mathrm{MW}$ \\
$600 \mathrm{wp}$ & N/A & N/A & $1.04 \mathrm{MW}$ \\
$300 \mathrm{wp}$ & N/A & N/A & $0.13 \mathrm{MW}$ \\
Total photovoltaic & & & $2.14 \mathrm{MW}$ \\
Total Installed capacity & & & $52.34 \mathrm{MW}$ \\
\hline
\end{tabular}

Wp: Watt peak capacity.

Isolated systems. Not connected to the National Electrical System (SEN) or to the National Interconnected System (SIN). Includes: Mini hydroelectric plants, Wind farm not integrated, Photovoltaic Systems.

of the investments has decreased, between 1950 and 1998 the gov ernment allocated the sum of US\$ 48,254 million to the electricity sector and from 1999 to 2014 it invested an additional amount of US\$ 96,128 million [50].

Considering this level of investments, the energy resources available and the development attained by the Venezuelan energy industry up to the 1990s, the existence of such energy deficit is inexplicable. Several experts attribute the problem to the prevalence of political over tech nical and financial decisions, to the inadequate use of financial re sources and to the centralization of the electric industry $[48,63,64]$.

From a technical perspective, the delays in the construction of the generation and transmission projects, the inadequate conditions of the different energy facilities due to the breach of maintenance plans, to gether with the overexploitation of the hydroelectric facilities and the mismanagement of the electricity system are elements that worsen the Venezuelan energy crisis $[63,65]$. As indicated by experts, and shown in Tables 25 , the situation of the construction and maintenance of energy facilities is critical. Due to inadequate maintenance and investment policies, there are several ongoing construction or refurbishment

Table 4

Venezuelan main electric generation projects evolution - wind.

Source: Authors' elaboration from: [52-55].

\begin{tabular}{|c|c|c|c|c|c|c|c|c|c|}
\hline $\begin{array}{l}\text { Plant/Project } \\
\text { type }\end{array}$ & Turbines & State & Capacity MW & $\begin{array}{l}\text { Project } \\
\text { begin }\end{array}$ & $\begin{array}{l}\text { Scheduled } \\
\text { start-up }\end{array}$ & $\begin{array}{l}\text { Installed } \\
\text { capacity in } \\
2013^{*}\end{array}$ & $\begin{array}{l}\% \text { of completion Aug } \\
\text { 2018. Corpoelec }\end{array}$ & $\begin{array}{l}\% \text { of completion Aug } \\
\text { 2018. Experts }\end{array}$ & $\begin{array}{l}\text { Planned } \\
\text { investments MM }\end{array}$ \\
\hline La Guajira/C & 76 & Zulia & 75.6 MW & 2011 & 2012 & $25.2 \mathrm{MW}$ & $\mathrm{N} / \mathrm{A}$ & 0 & $\$ 299 \mathrm{MM}$ \\
\hline Paraguana/C & 12 & Falcón & $98.8 \mathrm{MW}$ & 2006 & 2012 & $25 \mathrm{MW}$ & N/A & 30 & $\$ 299 \mathrm{MM}$ \\
\hline Chacopata/ C & 12 & Sucre & $24 \mathrm{MW}$ & N/A & $\mathrm{N} / \mathrm{A}$ & N/A & N/A & 0 & $\$ 75 \mathrm{MM}$ \\
\hline Nueva Esparta/C & 12 & $\begin{array}{l}\text { Nueva } \\
\text { Esparta }\end{array}$ & $24 \mathrm{MW}$ & N/A & 2013 & N/A & $\mathrm{N} / \mathrm{A}$ & 0 & $\$ 299 \mathrm{MM}$ \\
\hline
\end{tabular}

Project type: R: Refurbishment. C: Construction. 
Table 6

Venezuelan renewable energy generation in 2015. Gross electricity generation.

Source: [58].

\begin{tabular}{|c|c|c|c|c|c|c|c|c|}
\hline & Municipal waste & Industrial waste & $\begin{array}{l}\text { Primary solid } \\
\text { biofuels }^{\mathrm{a}}\end{array}$ & $\begin{array}{l}\text { Biogases liquid } \\
\text { biofuels }\end{array}$ & $\begin{array}{l}\text { Geothermal solar } \\
\text { thermal }\end{array}$ & Hydro & Solar PV & $\begin{array}{l}\text { Tide wave ocean } \\
\text { wind }\end{array}$ \\
\hline Unit & GWh & GWh & GWh & GWh & GWh & GWh & GWh & GWh \\
\hline Gross electric generation & 0 & 0 & 0 & 0 & 0 & 74 & 0 & 0 \\
\hline
\end{tabular}

a Data also available for charcoal.

projects still not completed after decades of work.

The Venezuelan renewable energy issues require special analysis. Beyond the traditional and extended use of hydropower, in the last decades, the Venezuelan government sustained positive initiatives for the development of renewable energy. The installation of PV systems, wind farms, hybrid systems as well as the creation of micro grids for isolated, indigenous or border communities as is the case of the "Sowing Light Project" promoted by FUNDELEC evidence the interest for renewable energy [59].

Unfortunately, the improvisation and mismanagement of those in itiatives led to the failure of such positive ideas and to severe setbacks in energy performance. The inability to update electricity rates, the indiscriminate and populistic extension of the subsidies policy, the failure to reduce the transmission and distribution losses and the scarce interest to promote and develop renewable projects are severe limita tions to their growth. These conditions are worsened by decisions that foster investments based on political and non sustainable criteria, mostly for the purchase of old and low quality equipment along with the development of energy agreements and alliances with Cuba and other countries in the region that frequently led to huge investments made abroad in detriment of the Venezuelan electricity sector. Posso et al. [66] point out the important available solar and wind resources existing in Venezuela. These authors state that such resources could contribute significantly to solving the country energy gaps mainly in isolated or rural areas, but the lack of information about their avail ability, conditions, and localization along with the inappropriate public policies makes it difficult to develop and take advantage of their ben efits.

Despite the problems described, in recent years, the Venezuelan regulatory framework has been adapted to include some regulations that promote the diversification of the energy matrix with renewable energy. In fact, it includes several laws and incentives related to re newable energy issues. Such regulations were designed to promote the generation and use of clean energies and to diversify the Venezuelan energy mix [42].

Among the existing regulations, the Venezuelan plan for the de velopment of the national electricity system for the 20132019 period [51] mentions the importance of increasing the availability of energy for the Venezuelan population based on sustainable criteria. This pro motes the use of alternative, renewable energies in addition to the fossil fuel energies. In such a plan, the Venezuelan government indicates the aim of supplying $500 \mathrm{MW}$ of energy from wind sources to be fully in corporated into the electric system by the year 2019 [51]. Notwith standing the positive initiative, that must be supported, this seems a very modest objective considering the country's potential and the cur rent dimension of the energy crisis.

Hernández [54] along with the Asociación Venezolana de Energía eólica (Venezuelan Wind Power Association) [67] highlight the im portance of research and academic development to be able to take advantage of the huge renewable energy resources in Venezuela. In their research, they propose additional efforts to develop renewable energy resources with the combined efforts of public and private in stitutions [68].

But the implementation of such plans has not been favorable. In fact, Vidoza and Gallo [62] indicate that the country has two wind farms still under construction after several years. The plan shows that when completed both plants would add a capacity of $36.3 \mathrm{MW}$. These units were the first of a pilot plan for a wind energy development de signed to take advantage of this potential. RVER [44] and Salas [69] have found that such wind facilities are now abandoned and not in production, as shown in Table 4.

Regarding solar power, there are few references about the Venezuelan initiatives for its development. Amongst these, there exist some approaches from the European Union, BID (Interamerican Development Bank), CAF (Corporación Andina de Fomento) and the Venezuelan government to create alliances oriented to develop the Venezuelan solar potential [70]. Other initiatives include the program "Sembrando Luz" (Sowing Light) created by the Foundation for the development of the Electric Services (FUNDELEC) [71]. This program is described as a way to supply renewable energies oriented to bring rural electrification to isolated indigenous or border communities. This or ganization states that 3139 systems have been installed in seven years. No official data regarding such projects have been found and in fact, Páez Pumar [56] indicates that there are small initiatives for the use of such resources but there are no details about them. REVE [72] alerts of its concerns that the Venezuelan government favors fossil fuel energy instead of renewables and has abandoned renewable initiatives, with results which are totally opposite to the incipient interest of renewables development.

To describe the current renewable energy overview, the authors confirmed the existence of some private enterprises to develop solar photovoltaic projects in Venezuela, both for industries as well as for residential purposes. Regrettably, there are no official records about them [70]. In general, experts warn that the existing Venezuelan reg ulatory framework makes wind and solar projects not competitive and this creates additional risks for the development of such energy po tential $[40,47,62]$. The severity of all such factors evidence the diffi culties to develop a sustainable energy sector in Venezuela $[31,66]$.

As a consequence, results show that the Venezuelan energy sector requires deep changes to support a higher awareness about the funda mental role of renewable energies to improve Venezuelan competi tiveness and to transform such learnings into actions and positive re sults. By this means, the framework presented calls for an energy transition to renewable energies with the imperative need to redirect Venezuela to the sustainable energy path.

\section{Discussion}

The facts described indicate that Venezuela presents serious pro blems that impede the country to be addressed into the path of sus tainability. The case is complex and multifaceted and covers an array of issues linked to the structure of the country and appear in legal, poli tical, technical, financial, environmental, managerial and social as pects. All need profound changes to make Venezuela capable of sup porting sustainable initiatives and improving country competitiveness.

To be able to improve, Venezuelan society must acknowledge the existence of structural problems that hinder the correct performance of its basic processes. Government management, public policies, energy, education, health, production, construction, finances, commerce, and $\mathrm{R}$ $\& \mathrm{D}$, must adapt to eliminate the causes that limit their performance. 
To be successful, such changes require holistic strategies, being aware of the existence of human and financial constraints. This requires the adaptation of the legal framework and policies leading to stable and long term sustainable goals. Such efforts must comprehend the revision of labor laws, currency and price controls, subsidies, safety, and re sources availability to correct their current faults and adapt them to sustainable competitive conditions.

The production of goods and services requires a critical selection of the priority projects to be developed. This includes the revision of their social and financing conditions, bidding terms, constructive strategies as well as technical and financial performance controls. This will enable the country to prioritize and plan the projects needed to be able to progressively create a solid foundation for the reconstruction of the entire productive system and thus obtain the best results from the limited resources available. These general changes must be supported by the specific strategies to be performed in every sector to promote a new vision of the country oriented to long term sustainable goals. The fullest utilization of the nation's potential and the achievement of im proved competitiveness and quality of life for the Venezuelan society will be some of the benefits to obtain.

\section{Recommendations to improve the Venezuelan energy sector}

Renewable energies have a fundamental role to play in order to support the improvement of the energy supply in Venezuela. The Venezuelan current conditions show that there is a long way to go before the country is ready for that. It is unmistakable that Venezuela needs an energy transition to reach the goals of sustainability and poverty reduction.

Based on the current national reality, the recommendations to im prove the Venezuelan energy sector will be presented from two dif ferent perspectives. First, considering the general framework needed for a better performance of the whole country and the energy industry in particular and in the second place, analyzing the specific tasks to be performed for the energy sector to generate, transmit and distribute electricity efficiently.

\subsection{General framework}

According to the data shown in Tables 1 6, the Venezuelan general and energy framework needs important revisions. The structure of the country's economy requires deep changes to recover a higher degree of independence and achieve conditions of productivity, competitiveness, and sustainability. Understanding the importance and the complexity of this main objective, in Table 7, the authors present some proposals to improve the national context where the energy processes must be de veloped and thus support the transition of this sector into the sustain ability path. This includes the revision of the existing conditions, reg ulations, and policies related to the entire country structure and with a focus on energy in particular and showing the identification of the improvement opportunities.

The implementation of the changes proposed should lead to the creation of a general foundation for greater independence, and condi tions for productive and competitive performances for all Venezuelan processes. Additionally, it should generate a new vision of common tasks and strategies for all the energy actors, including government, research centers, professional associations, and companies working together to improve global and sectorial performances.

\subsection{Specific tasks}

In addition to such general issues, the improvement of the energy sector requires the implementation of some specific tasks. This implies the identification of the main problems affecting this industry, its causes, the evaluation of the projects already started or needed as well as the establishment of the priorities among them. The comprehension of the resources available and required, the strategies to be performed, the use of knowledge management, the sustainability principles and the controls needed to evaluate and improve performance are part of such specific tasks. In Table 8, the authors included some of the proposals to improve the performance of the Venezuelan energy sector.

Other specific tasks to be completed include the evaluation of the current energy projects and the actions needed for their implementa tion. This evaluation must be performed based on the priorities and added value for the country. Table 9 includes some of the projects considered mandatory to address the transition of the Venezuelan en ergy sector from a traditional and non competitive performance to the renewable and sustainable path.

The combination of both general and specific measures should provide effective support for the reduction of the current legal and administrative barriers that currently discourage the participation of private investors. Additionally, the professional and technical man agement of the industry and the creation of incentives and tax benefits will lead to better performance, together with the increase of the energy efficiency and energy security for the benefit of the Venezuelan society.

\section{Conclusions}

With the aim of extracting learnings from the current energy ex periences and transform them into knowledge for better decisions, this research presents some facts related to the evolution of renewable en ergy and its fundamental importance for sustainability. The study considers the legal framework and policies needed for energy devel opment, with references to some insight into the Venezuelan energy sector and its improvement opportunities.

Not all countries have the best performance expected from their available resources. Venezuela is one of the countries that having a privileged natural endowment of energy resources presents an in adequate energy performance. This is evident if we consider that in the last few years the country shifted from being a world energy leader and one of the main oil and derivate producers and exporters, as well as one of the main world hydropower producers to become an oil, fuel and electricity importer with severe energy shortages and electricity ra tioning. As a consequence, in less than two decades the country has

Table 7

Recommendations to improve the Venezuelan energy sector.

Source: Authors' elaboration.

\begin{tabular}{|c|c|c|}
\hline \multicolumn{3}{|l|}{ General framework } \\
\hline Proposal & Objective & Responsible actors \\
\hline List of policies and regulations affecting the energy system & Database of sector conditions & Government, R\&D centers, companies. Experts \\
\hline List of conditions that support or limit the sustainable efforts & Database of improving areas & Government, R\&D centers, companies. Experts \\
\hline List of political \& legal changes needed & Database of improving areas & National Assembly. Experts \\
\hline Revise the energy tariffs \& subsidies & Restore the economic Balance & National Assembly. Experts \\
\hline List of controls needed & Control \& Surveillance & National Assembly. Experts \\
\hline Support Sustainable energy R\&D & Diversify energy mix. Sustainability & Universities, research centers \\
\hline
\end{tabular}


Table 8

Recommendations to improve the Venezuelan energy sector.

Source: Authors' elaboration.

\begin{tabular}{|c|c|c|}
\hline Proposal & Objective & Responsible actors \\
\hline List of problems: causes \& resources & Database. Improve performance & Government, R\&D centers, companies. Experts \\
\hline List of undergoing \& new projects. Prioritize & Projects database. Actions Planning & Government, R\&D centers, companies. Experts \\
\hline Identify the problem causes. & Learning, Planning \& Feedback & Energy responsible, R\&D Centers. Experts \\
\hline List of proposed strategies & Database. Actions planning & Energy leaders, R\&D Centers. Experts \\
\hline Share the Sustainable principles \& practices & Sustainable culture development & Government, R\&D centers, companies. Experts \\
\hline Evaluate the projects financial needs & Arrange financial aspects for projects performance & $\begin{array}{l}\text { Energy leaders, R\&D Centers. Experts. Multilateral } \\
\text { organizations }\end{array}$ \\
\hline Establish quality \& performance \& Indicators & Control \& Surveillance & Government, Energy leaders, professional associations. Experts \\
\hline Implement operative, management \& financial regulations & Performance controls. & Government, energy leaders, Multilateral organizations \\
\hline
\end{tabular}

fallen from having an acceptable quality of life and competitiveness index to holding bottom positions in such indicators. Thus the severity of the Venezuelan energy crisis cannot be hidden or minimized. This is a shocking paradox that researchers must study to identify its causes and work to reduce them, as a way to introduce the country into the sustainability path. The causes are complex and multidimensional. The country suffers from structural problems linked to a management model that does not favor a greater degree of independence, competitiveness or sustainability. This old management model implies the prevalence of the political management of the industry and creates severe obstacles to all national processes. This orientation, worsened by the lack of support to sustainability and competitiveness and the disregard for knowledge and lessons learned, lead to progressively worse performances in public management, education, health, construction, production, commerce, $\mathrm{R}$ $\& D$, and energy processes in Venezuela. The decline of the national competitiveness and quality of life are the worse consequences.

To offer some ideas about how to reverse these negative trends, the authors try to promote a critical and proactive review of the problem. This is particularly important due to the restrictions created by the management model that does not promote constructive criticism and the deep revision of the causes of the national problems. To try to avoid such constraints, the research evaluates the limitations of the public policies and the current energy situation in Venezuela and presents new data related to the situation of some of the infrastructure projects for hydro, thermal, wind and solar energy projects. The authors revise the gap existing between the installed capacity and the availability of en ergy.

The conclusion is that the main areas in which Venezuela needs to improve include the regulatory framework, the independence of public institutions, the control of investments and the incorporation of the sustainability criteria in all construction and maintenance projects. The authors present some proposals to support the Venezuelan transition from a traditional and noncompetitive energy sector to a new dynamic and sustainable industry based on the use of renewable energy. The proposals go from a general perspective which includes the revision of the public policies and the regulatory framework that sustain this in dustry and is extended to include the evaluation of the specific re newable and non renewable energy projects in execution or to be executed in Venezuela. The proposals incorporate the utilization of sustainability principles, the lessons learned and knowledge manage ment as fundamental resources to support the energy transition needed in Venezuela. Such basic guidelines may lead to new positive attitudes and patterns of behavior from both Venezuelan leaders and the popu lation facing these competitive challenges. This will enable Venezuela to take advantage of the huge energy resources available and become a sustainable energy leader and thus strengthen the improvement of competitiveness and the reduction of poverty. Finally, the authors propose the revision of Venezuelan energy crisis as a special chapter of world energy knowledge to be studied as a case of inappropriate energy management that arising from richness led Venezuela to severe energy poverty in a totally unjustified path contrary to all the signs of progress shown by global energy markets. This case deserves deep research and efforts to become a unique reference and a breaking point from the past mistakes to a new energy approach that may help to readdress Venezuela into the sustainability path and to avoid the repetition of similar cases in the future.

\section{Acknowledgments}

We acknowledge the technical support given by Manuel Uche Soria and Juan Salas for their valuable support with the revision of the ar ticle, the supply of information regarding the Venezuelan energy in frastructure and the use of renewable energy. We also acknowledge the World Bank Group and Solargis for the solar resource data obtained from the Global Solar Atlas, owned by the World Bank Group and provided by Solargis

Table 9

Recommendations to improve the Venezuelan energy sector.

Source: Authors' elaboration.

\begin{tabular}{|c|c|c|}
\hline Proposal & Objective & Responsible actors \\
\hline Completion of Paraguana \& La Guajira Wind projects (Table 4) & Wind potential development & Corpoelec-PDVSA/RVER \\
\hline Completion of Termozulia \& other thermoelectric projects (Table 3) & Restore energy mix balance & Corpoelec-PDVSA \\
\hline Improve the performance of the hydropower facilities. & $\begin{array}{l}\text { Release fossil fuel used for thermal plants. Restore hydro/ } \\
\text { thermal balance }\end{array}$ & Corpoelec \\
\hline Support the Sowing Light project (Table 3) & Support the development of wind PV microgrids & FUNDELEC/RVER \\
\hline Support other Renewable energy initiatives & Promote transition to renewable energy & RVER \\
\hline Promote incentives for better energy performance & Create social awareness o improve energy performance & Government /RVER \\
\hline $\begin{array}{l}\text { Support initiatives of electric self-generation for hospital, schools \& } \\
\text { industry }\end{array}$ & Temporary solution while the energy system is stabilized & $\begin{array}{l}\text { Government-Corpoelec-Private } \\
\text { companies }\end{array}$ \\
\hline
\end{tabular}




\section{Funding}

This research did not receive any specific grant from funding agencies in the public, commercial or not for profit sectors.

\section{References}

[1] CIB \& UNEP-IETC. Agenda 21 for sustainable construction in developing countries. Boutek report Bou/E0204; 2002.

[2] Iddrisu I, Bhattacharyya S. Sustainable energy development index: a multi-dimensional indicator for measuring sustainable energy development. Renew Sustain Energy Rev 2015;50:513-30.

[3] Pagani R. Journal of technology for architecture and environment. Oltre la crisi. Efficenza energetica e innovazione nei sistemi urbani: I trend che sfidano la crisi. Firenze: University press; 2011. p. 54-61. [Techne].

[4] Jefferson M. Sustainable energy development: performance and prospects. Renew Energy 2006;31:571-82.

[5] Mocarquer S, Barroso L, Rudnick H, Bezerra B, Pereira M. Balance of power. IEEE Power Energy Mag 2009.

[6] Apergis N, Danuletiu D. Renewable energy and economic growth: evidence from the sign of panel long-run. Int J Energy Econ Policy 2014;4(4):578-87.

[7] Al-mulali U, Fereidouni H, Lee J, Sab C. Examining the bi-directional long-run relationship between renewable energy consumption and GDP growth. Renew Sustain Energy Rev 2013;22(209-222):2013.

[8] Al Mulali U, Fereidouni H, Lee J. Electricity consumption from renewable and nonrenewable sources and economic growth: evidence from Latin American countries. Renew Sustain Energy Rev 2014;30(290-298):2014.

[9] Muneer T, Asif M. Energy supply, its demand and security issues for developed and emerging economies. Renew Sustain Energy Rev 2007;11(1388-1413):2007.

[10] Holm D. Renewable energy future for the developing world. ISES International Solar Energy Society; 2005〈http:/ whitepaper.ises.org 〉 [Accessed 6 May 2016].

[11] Tracking SDG7. The energy progress report 2018. IEA/IRENA/United Nations Statistic Division/World Bank Group/World Health Organization; 2018.

[12] Global energy transformation. A roadmap to 2050. Irena; 2018.

[13] Energy Access Outlook 2017. From poverty to prosperity. IEA; 2017.

[14] Bhide A, Rodríguez-Monroy C. Energy poverty: a special focus on energy poverty in India and renewable energy technologies. Renew Sustain Energy Rev 2011;15(1057-1066):2011.

[15] Chen S, Ravallion M. The developing world is poorer than we thought but not less successful in the fight against poverty. The World Bank Development Research Group. Policy research working paper 4703; 2009 .

[16] Fuso F, Broad O, Mentis D, Welsch M, Bazilian M, Howells M. A cost comparison of technology approaches for improving access to electricity services. Energy 2016;95(255-265):2016.

[17] Pietrosemoli L, Rodríguez-Monroy C. The impact of sustainable construction and knowledge management on sustainability goals. A review of the Venezuelan renewable energy sector. Renew Sustain Energy Rev 2013;27(683-691):2013.

[18] Pero M, Moretto A, Bottani E, Bigliardi B. Environmental collaboration for sustainability in the construction industry: an exploratory study in Italy [/2071-1050/ 9/1]. Sustainability 2017;9(1). [/2071-1050/9/1].

[19] Kreuzer F, Wilmsmeier G. Naciones unidad. CEPAL Eficiencia energética y movilidad en América Latina y el Caribe. Una hoja de ruta para la sostenibilidad. Colección documentos del proyecto; 2014

[20] Rudnick H. Pioneering electricity reform in South America. IEEE Spectr 1996;33(8):1996. [38-44].

[21] Joskow P. Electricity sector restructuring and competition: lessons learned. Cuad. econ. Vol. 40, no. 121 Santiago; 2003.

[22] Zilio M, Recalde M. GDP and environment pressure: the role of energy in Latin America and the Caribbean. Energy Policy 2011:39(12):7941-9.

[23] EIA 2011. US energy information administration. International Energy Outlook; 2011

[24] BP 2017. Statistical review of World energy. June 2017. 66th edition; 2017.

[25] EIA 2017. Annual energy outlook with projections to 2050. 〈www.eia.gov/aeo〉 [Accessed 5 September 2017].

[26] Girard A, Gago E, Ordoñez J, Muneer T. Spain’s energy outlook: a review of the PV potential and energy export. Renew Energy 2016;86(703-715):2016.

[27] 12 countries leading the way in renewable energy. 〈http:www.clickenergy.com.au/ news-blog/12-countries-leading-the $>$ way-in-renewable-energy. [Accessed 1 December 2019].

[28] Renewable energy World. Bright outlook for wind power in Latin America Aug 21; 2018. 〈https://www.renewableenergyworld.com/ugc/articles/2018/08/20/latinamerica-roundup.html〉. [Accessed 15 January 2019].

[29] Exxon Mobil. The outlook for energy: A view to 2040. exxonmobil.com/energyoutlook;2012. [Accessed 20 June 2013].

[30] Scarlats N, Dallemand J, Monforti-Ferrario F, Banja M, Motola V. Renewable energy policy framework and bioenergy contribution in the European Union. An overview from national renewable action plans. Renew Sustain Energy Rev 2016;51(969-985):2017.

[31] Canseco M. Energías renovables en América Latina. Fundación Ciudadanía y Valores; 2010. 〈http://plataforma.responsable.net/sites/default/files/ 1279184521 energias renovables en america latina.pdf $>$.

[32] Fisher R, Serra P. Regulating the electricity sector in Latin America [Fall 2000]. Economía 2000:1(1):155-98.

[33] Israel A, Rodriguez-Monroy C. Review of Mexico's energy reform in 2013:
Background, analysis of the reforms and reactions. Renew Sustain Energy Rev 2016;58:725-36.

[34] Bautista S. A sustainable scenario for Venezuelan power generation sector in 2050 and its costs. Energy Policy 2012;44(331-340):2012.

[35] Oteyza C. El Reventón. Los inicios de la producción petrolera en Venezuela (1883-1943). Cine Archivo Bolívar Films. Serie Temática. Colección archive BF; 2008.

[36] Pietrosemoli L, Rodríguez-Monroy C. Renewable energy infrastructure. A challenge for Venezuelan industrial construction. In: Proceedings of the 10th Latin American and Caribbean conference for engineering and technology. Panama city, Panama; 2012.

[37] Tellería R. Historia del desarrollo del sector eléctrico en Venezuela. 1880-1998. Caracas; 2014. 〈https://www.scribd.com/document/266370580/VenezuelaHistoria-Del-Desarrollo-Del-Servicio-Electrico-Rodolfo-Telleria $>$.

[38] Project Management Institute. The guri dam. Case study PMI; 2006.

[39] Méndez N. Universidad Central de Venezuela. Hitos del proceso Histórico-Social de la Ingeniería Venezolana 1958-1998. Revista de la Facultad de Ingeniería. Vol. 25 No. 2; 2010, p. 51-66. 〈http://www.scielo.org.ve/scielo.php?Script = sci arttext\& pid $=$ S0798-40652010000200006

[40] Pietrosemoli L, Rodríguez-Monroy C. Renewable energy infrastructure. Importance to reach sustainability goals. The Venezuelan situation in 2016. In: Proceedings of the 14th LACCEI international multi-conference for engineering, education, and technology: engineering innovations for global sustainability, 20-22 July 2016, San José, Costa Rica; 2016

[41] BP Energy Outlook. Edition. Outlook to 2035; 2016. 〈https://www.bp.com/ content/dam/bp/pdf/energy-economics/energy-outlook-2016/bp-energy-outlook2016.pdf $>$. [Accessed 23 February 2017].

[42] IRENA. International renewable energy agency; 2015. 〈www.irena.org/ documentdownload/publication> Renewable Energy Policy Brief Venezuela.

[43] Salas J Alternativas energéticas planteadas a mediano termino como solución a la baja calidad de vida, la inseguridad eléctrica y al alto impacto ambiental de la costa occidental del lago de Maracaibo 〈http://redvenr.blogspot.com〉. [Accessed 19 January 2019].

[44] Red Venezolana de Energía Renovable RVER 〈http://redvenr.blogspot.com/〉. [Accessed 28 July 2018].

[45] Hernández N. La matriz energética venezolana. Conversatorio sobre realidades globales sobre la energía y el petróleo; 2017. 〈https://app.box.com/s〉.

[46] González-Longatt F, Serrano González J, Burgos Payan M, Riquelme Santos J. Windresource atlas of Venezuela based on on-site anemometry observation. Renew Sustain Energy Rev 2014;39(898-911):2014.

[47] Gonzalez-Longatt F. Wind resource potential in Los Taques Venezuela. IEEE Am Lat 2015;13(5):1429-37.

[48] Colegio de ingenieros de Venezuela. Crisis en el Sistema Eléctrico Nacional Caracas; April 2016. 〈http://www.civ.net.ve/〉.

[49] Portillo C. Foro Crisis eléctrica en Venezuela. Dónde estamos, hacia dónde vamos. Colegio de Ingenieros del Estado Zulia. Maracaibo; April 2016. 〈http:// centrodeingenierosdelzulia.com.ve/ $>$.

[50] Portillo C. Foro Servicios en Crisis. Sin Luz y sin transporte. ¿A dónde fue el gasto público? Cámara de Comercio de Maracaibo. Junio; 2016. 〈http://www.ccm.org. ve/>.

[51] Ministerio para el Poder Popular para la Energía Eléctrica. Plan de desarrollo del Sistema Eléctrico Nacional. PDSEN 2013-2019. 〈https://www.slideshare.net/ IsmarAdrian/venezuela-plan-electrico-2013-2019〉. [Accessed 28 June 2018].

[52] Corpoelec; 2018. 〈http://www.corpoelec.gob.ve/proyectos〉. [Accessed 08 April 2018].

[53] Salas J. Indagación sobre situación del sector energético en Venezuela. July 2018. Data collected from: Aguilar J. La ruta eléctrica en Venezuela. Grupo Ricardo Zuloaga 2015/Caveinel. Mesa redonda sobre la industria eléctrica; 2004/Colegio de ingenieros de Venezuela. Abril; 2016/Hernández N. La crisis energética en Venezuela. Blog Gerencia y Energía. May; 2011 Lara Guzman M. La crisis eléctrica en Venezuela. Grupo Ricardo Zuloaga May; 2015/Páez Pumar E. La crisis eléctrica en Venezuela; Asociación integral de políticas públicas.

[54] Hernández N. Las Energías alternativas. Universidad Simón Bolívar. Blog Gerencia y Energía; 2010. 〈https://www.slideshare.net/energia/energias-alternativas-finalfudesev-2010〉.

[55] Ministerio para el Poder Popular para la Energía Eléctrica. MPEEE. Memoria y Cuenta 2014; 2015. 〈http://www.derechos.org.ve/pw/wp-content/uploads/ MemoriaElectrica $>$ 2014.pdf.

[56] Ministerio del Poder Popular para la Energía Eléctrica, MPPEE web page. 〈http:// mppee.gob.ve/> [Accessed 10 July 2018].

[57] Páez E. Generación eléctrica a partir de residuos sólidos en Caracas Congreso Internacional de Energías Renovables y Sustentables, para Ingenierías COENERGY 2018 - Edición Desarrollo Industrial y Urbano EDUCA INTERNACIONAL Isla de Margarita, Venezuela; 2018.

[58] IEA. International energy agency statistics. Venezuela; 2017. 〈http://www.iea.org/ statistics/statisticssearch/report/?Country $=$ Venezuela\&product $=$ RenewablesandWaste> [Accessed 23 October 2017].

[59] Salas J. Avance Actual de las Energías Renovables y del Desarrollo Sustentable en la América del Sur y el Mundo. Congreso Internacional de Energías Renovables y Sustentables, para Ingenierías COENERGY 2018 - Edición Desarrollo Industrial y Urbano EDUCA INTERNACIONAL. Isla de Margarita, Venezuela; 2018.

[60] World Economic Forum. Global competitiveness report 2017-2018; 2017. ISBN-13: 978-1-944835-11-8.

[61] Aguilar J Estamos en puertas de un gran apagón nacional. El Carabobeño, [Accessed 3 August 2018].

[62] Vidoza J, Gallo W. Projection of fossil fuels consumption in the Venezuelan 
electricity generation industry. Energy 2016;104(237-249):2016.

[63] Grupo Ricardo Zuloaga. La Crisis eléctrica: Grupo Ricardo Zuloaga a la Asamblea Nacional. Caracas; February 2016. 〈http://www.lossinluzenlaprensa.com/wpcontent/uploads/2016/02/El-Grupo-Ricardo-Zuloaga-a-la-Asamblea-Nacional-2de-febrero-de-2016.pdf $>$.

[64] CIDEZ. Centro de Ingenieros del Estado Zulia. Notas de Prensa 2017, 2016, 2015 2017. 〈http://centrodeingenierosdelzulia.com.ve/〉. [Accessed 15 May 2018].

[65] Prodavinci. ¿Qué está pasando con el sistema eléctrico? ¿Por qué hay una crisis eléctrica? 26 February; 2016. 〈http://prodavincicom/〉.

[66] Posso F, González J, Guerra F, Gómez H. Estimación del potencial de energía solar en Venezuela utilizando Sistemas de Información Geográfica. Estimation of the solar energy potential in Venezuela by using Geographical Information Systems. Revista Geográfica Venezolana. Vol. 55(1); 2014, p. 27-43. 〈https://www. researchgate.net/profile/FAUSTO POSSO/publication/287311934 Estimation of the solar $>$.

[67] Asociación Venezolana de Energía Eólica AVEOL. Venezuelan eolic association;
2017. 〈https://www.evwind.com/tags/asociacion-venezolana-de-energia-eolica/ 〉. [Accessed 8 August 2017].

[68] REVE. Revista Eólica y del Vehículo Técnico. Eólica en Venezuela analiza los avances del sector eólico en la Universidad Simón Bolívar. 22 October; 2014. 〈https://www.evwind.com/tags/asociacion-venezolana-de-energia-eolica/〉. [Accessed 8 August 2017].

[69] Salas J. Logros y lecciones aprendidas de los desarrollos de energías renovables nuevas en el país 1959-2013; 2018. 〈http://redvenr.blogspot.com/〉 [Accessed 28 July 2018]

[70] Conexsol. Anthony Lopez. Conexol CEO. Interview. February 18, 2017; 2017.

[71] FUNDELEC. 2017. 〈http://www.fundelec.gob.ve/?Page id $=758\rangle$. [Accessed 8 September 2017].

[72] REVE. El abandono de los proyectos de energías renovables en Venezuela; 2016 〈https://www.evwind.com/2016/07/29/el-abandono-de-los-proyectos-deenergias-renovables-en-venezuela $\rangle$. [Accessed 8 September 2017]. 